\title{
Growth Potential of Camelus dromedarius Calves Reared under Intensive and Extensive Feeding Management Systems
}

\author{
Asim Faraz* \\ Department of Livestock and Poultry Production, Faculty of Veterinary Science, \\ Bahauddin Zakariya University Multan, Pakistan
}

\begin{abstract}
A B S T R A C T
A four-month study was carried out to check the growth potential of Marecha (Camelus dromedarius) calves in intensive management system (IMS) and extensive management system (EMS) in Thal desert, Punjab Pakistan. Twelve male and female calves were divided into two comparable groups of six each containing three males and three females. The first group calves were fed concentrate @ $1 \mathrm{~kg} / \mathrm{h} / \mathrm{d}$ plus crop residues of gram (Cicer arientinum) ad libitum while in second group calves were allowed grazing/ browsing for $10 \mathrm{~h}$ daily along with household refusals. Twice watering was provided. Fortnightly weighing of calves was done by digital scale. Data collected on different parameters was subjected to statistical analysis with $2 \times 2$ factorial arrangements of treatments under completely randomized design. After 120 days trial period the mean body weight and average daily gain (ADG) of male and female calves was significantly increased $(\mathrm{P}<0.05)$ in IMS as $80.8 \pm 2.7,77.8 \pm 2.7 \mathrm{~kg}$ and $0.67 \pm 0.02,0.65 \pm 0.02$ $\mathrm{kg} / \mathrm{d}$ than EMS as $64.7 \pm 2.6,52.3 \pm 2.6 \mathrm{~kg}$ and $0.54 \pm 0.02,0.44 \pm 0.02 \mathrm{~kg} / \mathrm{d}$ of male and female calves. Intake of crop residues $(\mathrm{P}<0.05)$ was found to be $6.9 \pm 0.45$ and $6.4 \pm 0.45 \mathrm{~kg} / \mathrm{d}$ in male and female calves, respectively in IMS and $3.5 \pm 0.23$ for male and female calves both in EMS. The total feeding cost per calf for 120 days was higher in IMS than EMS while the cost per kg body weight gain was less and economical in the former as compared to the latter group. In behavioral preference the first in order was kari (Capparis spinosa), dhaman (Cenchrus ciliaris) and kikar (Acacia nilotica) among bushes, grasses and trees, respectively for male and female calves in EMS
\end{abstract}

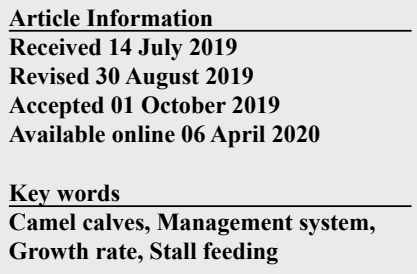

ation

Available online 06 April 2020

Camel calves, Management system,

Growth rate, Stall feeding

\section{INTRODUCTION}

$\mathrm{F}$ ace to the human population growth, the food security is nowadays a big challenge for developing countries. The need of hour is to explore new resources which are indigenous and not fully exploited yet. The camel is a future hope in this regard (Faraz et al., 2019a). Camel is an important source of food subsistence and income for the pastorals, arid and semi-arid people (Faye, 2016). Camel can survive and produce in severe, hot and hostile environments with equally good potential as other domestic animals in favorable environment (Ahmad et al., 2010; Faraz et al., 2013). It is a best food source for dry areas nourishing the bedouins, nomads and pastoralists since centuries (Raziq et al., 2008).

Camel can utilize poor quality forages with much more efficiency, as it retains fiber in its fore stomach for long as $70 \mathrm{~h}$ (Von Engelhardt et al., 2006). It performs reutilization of urea for microbial protein synthesis and can use water economically for almost all metabolic functions.

\footnotetext{
* Corresponding author: drasimfaraz@bzu.edu.pk 0030-9923/2020/0004-1493 \$ 9.00/0

Copyright 2020 Zoological Society of Pakistan
}

With 1.1 million heads (FAOSTAT, 2019; GOP, 201718), camel population in Pakistan is enough to contribute to food security in the national economy and for the areas of diverse ecozones. However, for contributing to this, improvement of the meat productivity in camel herd is necessary. One way could be a more intensive feeding to increase the growth of young camels. Hence this study was planned to evaluate the growth potential in intensive and extensive management systems in its natural habitat.

\section{MATERIALS AND METHODS}

\section{Study area and meteorological conditions}

This study was conducted at Camel Breeding and Research Station (CBRS), Rakh Mahni, Tahsil Mankera, District Bhakkar. The CBRS is located in Thal area between $31^{\circ} 10^{\prime}$ and $32^{\circ} 22^{\prime}$ ' North Latitude and $70^{\circ}$ $47^{\prime}$ and $72^{\circ}$ East Longitude. Most of the area lies in the desert plain of the Thal. This area is included in the Agro Ecological Zone-III A and B (sandy desert area) having narrow strips of sand ridges and sand dunes. The climate is arid to semi-arid subtropical continental and mean monthly highest temperature goes up to $45.6{ }^{\circ} \mathrm{C}$, while in winter it goes from 5.5 to $1.3{ }^{\circ} \mathrm{C}$. Mean annual rainfall in the region 
ranges from 150-350 mm, increasing from South to North (Rahim et al., 2011).

\section{Animal management}

Camel calves belonging to Marecha breed, maintained at Camel Breeding and Research Station (CBRS) Rakh Mahni, Tahsil Mankera, District Bhakkar and from the nearby field were used for this experiment to compare the efficiency of body weight gain in camel calves raised under intensive (IMS) and extensive feeding system (EMS). Twelve Marecha calves (Camelus dromedarius) around $330 \pm 30$ days of age having group weight of 135,0 and $134,0 \mathrm{~kg}$, respectively were used in 120 days trial with 15 days additional as adaptation period. Of these, six (3 males and 3 females) belonged to the CBRS reared under IMS and the other six calves ( 3 males and 3 females) were owned by private farmers reared under EMS. Before the start of experiment all the camel calves were marked for identification and dewormed to reduce the parasitic load. Calves were housed in semi-open pens throughout the trial at farm in IMS while under available housing in EMS. Initial body weights of the camel calves were recorded before shifting these calves to the respective treatment groups and thereafter all the experimental calves were weighed fortnightly on digital weighing scale (Impressum Pakistan) before morning feeding.

\section{Experimental animals and feeding plan}

The groups were composed on homobreed and heterosex calves. Water was provided twice a day in both the systems. The animals in the first group were fed concentrate@1 kg/h/d along with crop residues of gram (Cicer arientinum) round the clock, considered as IMS. The ingredients of experiments are maize grain $9 \%$, wheat bran $24 \%$, cotton seed cake $25 \%$, rape seed cake $6 \%$, corn gluten $20 \%$, molasses $14 \%$, DCP $1 \%$, salt $1 \%$. The chemical composition of experimental ration is DM 90.32\%, CP 18.06\%, NDF 29.09\%, ADF 14.41\%, TDN 70\%, ME (Mcal/kg DM) 2.41\%. While in EMS, calves were allowed grazing/browsing for 10-12 h (as per prevailing practice) along with feeding of households (kitchen waste, house refusal and some grains).

\section{Data collection}

Daily growth rate (ADG) was calculated by fortnightly weighing as current weight-previous weight $/ 15$. The feed intake of crop residues was calculated as the difference between the residual amount of feed and the amount offered. The average dry matter values of feed were measured and the dry matter intake (DMI) was then determined. The choice of vegetation (grazing duration) was observed and the data was coded on a five-points scale refers to the choice among bushes, grasses, trees (Bhakat et al., 2008). Feed intake of different grazing/browsing species of camel calves under EMS was estimated by behavioral method described by Wilson (1998) and by using NDF values in the formula (Schroeder, 2013).

\section{Laboratory analysis}

The concentrate, crop residues and herbage samples of the grazing/browsing material were analyzed for percent dry matter, crude protein, crude fiber, ether extract and ash (AOAC, 1997). Neutral detergent fiber (NDF) and acid detergent fiber (ADF) was also determined (Van Soest et al., 1991).

\section{Statistical analysis}

Data collected on different parameters were analyzed statistically by using Fisher's analysis of variance technique having $2 \times 2$ factorial arrangements of treatments under CRD using GLM of SPSS software (SPSS, 2008). Tukey's test at 0.05 levels of significance was used to compare the differences among the treatment means (Steel et al., 1997).

\section{RESULTS AND DISCUSSION}

\section{Effect of sex on growth}

In present study, male calves attain higher weights in both the systems, may be due to the reason that more receptors are present on muscle cells for androgens that accelerates the growth (Hossner, 2005). The highest growth of young males is a common feature in most of the farm animals and was widely reported in the literature. In camel for example, similar observations were done in Pakistan by Knoess (1977) and Qureshi (1986) who reported average daily weight gain as $1400 \mathrm{~g}$ in male, $950 \mathrm{~g}$ in female; $1500 \mathrm{~g}$ in male, $1000 \mathrm{~g}$ in female camel calves, respectively. Sahani et al. (1998) in India reported average daily gain in $0-3(630,580)$; $3-6(640,620)$; 6-9 (370, 390); 9-12 (230, 230); 18-24 (160, 200); 24-30 (160, $170)$ and 30-36 months $(180,140) \mathrm{g}$ in male and female calves, respectively. Khanna et al. (2004) reported average daily gain (ADG) as 700 and $770 \mathrm{~g}$ in Jaisalmeri and Bikaneri Indian camel breeds from birth to 3 months of age, respectively. However, no significant difference was found between male and female calves regarding their daily weight gain. Bakheit et al. (2012) studied the effect of management system on growth rate of calves in North Kordofan, Sudan and found no significant difference between male and female calves regarding their daily weight gain.

Ouda et al. (1992) studied production performance of Somali and Rendille camels in northern Kenya and 
observed that sex and year affects significantly growth after two years of age. Kurtu (2004) reported that mature male calves were heavier than female calves by $38 \%$ in Ethiopia. Reported weight gain in calves was $411 \mathrm{~g} / \mathrm{d}$ in males and $380 \mathrm{~g} / \mathrm{d}$ in females while weight gain after the sexual maturity was $120 \mathrm{~g} / \mathrm{d}$ in males and $60 \mathrm{~g} / \mathrm{d}$ in females in northern Kenya (Musavaya, 2003). Faraz et al. (2017, $2018,2019 b$ ) compared the growth performance of camel calves in different management systems and found higher weight gain in male calves than female calves.

\section{Effect of diet on growth}

The calves of almost similar weights were selected in both management systems for this study. After 120 days of trial period overall weight gain and daily weight gain (growth rate) was $80.8 \pm 2.7,77.8 \pm 2.7 \mathrm{~kg}$ and 670 , $650 \mathrm{~g} / \mathrm{d}$ of male and female calves, respectively in IMS and $64.7 \pm 2.6,52.3 \pm 2.6 \mathrm{~kg}$ and $540,440 \mathrm{~g} / \mathrm{d}$ of male and female calves, respectively in EMS (Table I). The average daily gain significantly varied between groups being significantly higher in IMS than EMS for females but not for males (Table I). These findings are in line with those of Bhakat et al. (2008) who studied the effect of management systems on growth performance of dromedary camel calves in India. They used 10 camel calves aged between 7-10 months old in their study and divided them randomly into two comparable groups of 5 each. The average initial body weight of both groups was almost similar. The groups were of hetero breed and sex combinations, each group contained 3 Jaisalmeri, 1 Bikaneri, 1 Katchi breed and 4 males and 1 female. At the end of the trial, average total gain was almost double in ISM than SISM group. The average growth rate was significantly higher in ISM (611 $\mathrm{g} / \mathrm{d})$ than SISM $(319 \mathrm{~g} / \mathrm{d})$.

Contrary to our observations, Bhakat et al. (2009) reported that the average daily gain $(\mathrm{g} / \mathrm{d})$ differed significantly among two systems, being higher in SIMS as $(325$ and $476 \mathrm{~g} / \mathrm{d})$ than IMS as $(278$ and $331 \mathrm{~g} / \mathrm{d})$ with guar phalgati (Cyamopsis tetragonoloba) and moth chara (Phaseolus aconitifolius) feeding, respectively. In another context, in Sudan, Bakheit et al. (2012) studied the effect of management system on growth rate of calves and reported that daily growth rate was 534 and $316 \mathrm{~g} / \mathrm{d}$ in semi-intensive and traditional management systems, respectively.

Saini et al. (2014) also reported higher total and average daily gain $(\mathrm{kg})$ in stall fed pre-pubescent camels as compared to grazing group. In Sudan Mohamedain et al. (2015) studied growth performance in dromedary camels under two feeding regimens. First was zero browsing group (15 Darfuri and 10 Butana) fed complete ration (sorghum $50 \%$, groundnut cake $15 \%$, wheat bran $5 \%$, molasses $10 \%$, dura husk $5 \%$, bagasse $12 \%$, urea $2 \%$ and common salt $1 \%$ ) to provide ME @ 11 MJ/kg DM and 16\% CP. Second was free browsing group with same breeds without any supplement. The trial was of 120 days with two weeks as adaptation period. The average total weight gain was almost double in zero browsing group $(96 \pm 17.3 \mathrm{~kg})$ than free browsing group $(42 \pm 19.5 \mathrm{~kg})$. ADG was $800 \mathrm{~g}$ in zero browsing group as compared to $350 \mathrm{~g}$ in free browsing group. While in present study, lower daily weight gain was observed in IMS due to the limited supply of concentrate.

Dabiri et al. (2003) reported average daily weight gain as $700 \mathrm{~g}$ in camels at 1-2 years old in traditional management system. In Kenya under proper nutrition reported average daily weight gain in camel calves was 870 and $570 \mathrm{~g}$ from birth to 30 days and from birth to 180 days, respectively (Wilson, 1992) while in Egypt ElBadawi (1996) reported 830-970 g daily weight gain from birth to 180 days in dromedary calves. Faraz et al. (2018) comparing intensive management system (IMS) with semi-intensive management system (SIMS) regarding growth rate of camel calves found also higher growth rate in male calves under IMS than SIMS. The values of present study also very close to their other study reported in which higher growth rates was achieved in EMS than SIMS (Faraz et al., 2017). Current findings are also in agreement with our former study (Faraz et al., 2019b) in which we compared the growth performance and hair mineral status of Marecha calves in different management systems and found significant increase in the average daily gain of male and female calves being higher in intensive management system than semi-intensive management system.

\section{Feed intake}

The daily feed intake (DFI) of crop residues was found to vary significantly $(\mathrm{P}<0.05)$ among calf groups between IMS and EMS being higher in IMS than EMS. Intake of crop residues was found to be $6.9 \pm 0.45$ and $6.4 \pm 0.45 \mathrm{~kg} / \mathrm{d}$ in male and female calves, respectively in IMS and $3.5 \pm 0.23$ for male and female calves both in EMS. The weight gain for one $\mathrm{kg}$ intake of crop residues as conversion index is 97.1 and $101.5 \mathrm{~g} / \mathrm{kg}$ ADI for males and females, respectively in IMS and 154.3 and $125.7 \mathrm{~g} / \mathrm{kg}$ ADI for males and females, respectively in EMS (Table II).

In the study of Bhakat et al. (2008) regarding the effect of management systems on growth performance of Indian camel calves, it was reported that the crop residue intake significantly varied between two groups, 5.53 vs. $4.37 \mathrm{~kg} / \mathrm{calf} / \mathrm{d}$ in ISM and SISM, respectively. Moreover, Saini et al. (2014) reported higher DMI (kg/d) in stall fed prepubescent camels as compared to grazing group.

In the study of Bhakat et al. (2009) who determined growth characteristics of Indian camel calves under ISM 
Table I. Overall weight gain $(\mathrm{kg})$ and growth rate $(\mathrm{kg} / \mathrm{d})$ of male and female camel calves in IMS and EMS.

\begin{tabular}{llllll}
\hline Parameter & \multicolumn{2}{c}{ IMS } & & \multicolumn{2}{c}{ EMS } \\
\cline { 2 - 3 } \cline { 5 - 6 } & Male & Female & & Male & Female \\
\hline Growth at 30 d & $21.7 \pm 0.9^{\mathrm{a}}$ & $20.3 \pm 0.9^{\mathrm{a}}$ & & $17.7 \pm 1.0^{\mathrm{a}}$ & $14.6 \pm 1.0^{\mathrm{b}}$ \\
Growth at 60d & $20.2 \pm 0.6^{\mathrm{a}}$ & $19.7 \pm 0.6^{\mathrm{a}}$ & & $16.4 \pm 0.8^{\mathrm{a}}$ & $14.3 \pm 0.8^{\mathrm{b}}$ \\
Growth at 90d & $19.7 \pm 0.7^{\mathrm{a}}$ & $19.2 \pm 0.7^{\mathrm{a}}$ & & $15.4 \pm 0.7^{\mathrm{a}}$ & $12.5 \pm 0.7^{\mathrm{b}}$ \\
Growth at 120 d & $19.3 \pm 0.6^{\mathrm{a}}$ & $18.7 \pm 0.6^{\mathrm{a}}$ & & $15.0 \pm 0.6^{\mathrm{a}}$ & $11.5 \pm 0.6^{\mathrm{b}}$ \\
Overall weight gain & $80.8 \pm 2.7^{\mathrm{a}}$ & $77.8 \pm 2.7^{\mathrm{a}}$ & & $64.5 \pm 2.6^{\mathrm{a}}$ & $52.9^{\mathrm{a}} \pm 2.6^{\mathrm{b}}$ \\
Daily weight gain & $0.67 \pm 0.02^{\mathrm{a}}$ & $0.65 \pm 0.02^{\mathrm{a}}$ & & $0.54 \pm 0.02^{\mathrm{a}}$ & $0.44 \pm 0.02^{\mathrm{b}}$ \\
\hline
\end{tabular}

Means having different superscript in columns are significantly different $(\mathrm{P}<0.05)$

Table II. Average male and female camel calves' intake of crop residues (kg) \& conversion index (g/kg ADI) on DM basis in IMS and EMS.

\begin{tabular}{|c|c|c|c|c|}
\hline \multirow[t]{2}{*}{ Parameter } & \multicolumn{2}{|c|}{ IMS } & \multicolumn{2}{|c|}{ EMS } \\
\hline & Male & Female & Male & Female \\
\hline ADI in $30 \mathrm{~d}$ & $6.5 \pm 0.44^{\mathrm{a}}$ & $5.9 \pm 0.44^{\mathrm{a}}$ & $3.3 \pm 0.22^{\mathrm{b}}$ & $3.3 \pm 0.22^{b}$ \\
\hline ADI in $60 \mathrm{~d}$ & $6.9 \pm 0.45^{\mathrm{a}}$ & $6.4 \pm 0.45^{\mathrm{a}}$ & $3.5 \pm 0.23^{\mathrm{b}}$ & $3.6 \pm 0.23^{b}$ \\
\hline ADI in $90 \mathrm{~d}$ & $7.5 \pm 0.46^{\mathrm{a}}$ & $6.8 \pm 0.46^{\mathrm{a}}$ & $3.8 \pm 0.24^{\mathrm{b}}$ & $3.8 \pm 0.24^{\mathrm{b}}$ \\
\hline ADI in $120 \mathrm{~d}$ & $7.9 \pm 0.45^{\mathrm{a}}$ & $7.4 \pm 0.45^{\mathrm{a}}$ & $4.0 \pm 0.25^{b}$ & $4.0 \pm 0.25^{b}$ \\
\hline Daily feed intake/animal & $6.9 \pm 0.45^{\mathrm{a}}$ & $6.4 \pm 0.45^{\mathrm{a}}$ & $3.5 \pm 0.23^{b}$ & $3.5 \pm 0.23^{b}$ \\
\hline Conversion index & 97.1 & 101.5 & 154.3 & 125.7 \\
\hline
\end{tabular}

Means having different superscript in columns are significantly different $(\mathrm{P}<0.05)$

and SISM, non-significant intake was found by using Guar phalgati chara (Cyamopsis tetragonoloba) (6.02 vs. 5.14 $\mathrm{kg} / \mathrm{calf} / \mathrm{d}$ ) but significant with moth chara (Phaseolus aconitifolius) (7.91 vs. $6.24 \mathrm{~kg} /$ calf/d), respectively. Furthermore, in the study of Tandon et al. (1993), the dry fodder and water intake was positively correlated with the growth of weaned calves. Moreover, dry matter intake (DMI) was also found to be positively correlated in Indian camel calves (Singh et al., 2000). The findings of present study confirmed the values reported by Faraz et al. (2019b) who compared the IMS with SIMS and found higher crop residues intake in male and female calves under IMS than SIMS. In another study Faraz et al. (2017) compared the growth performance of dromedary calves reared under EMS and SIMS and found higher feed intake in EMS than SIMS. Such differences in feed intake could be due to the higher part of cellulose in grazing diet. It is linked also to the time spent for grazing. In all intensive systems, animal in close pen do not spend time for grazing and do not loss energy for walking, consequently their feeding capacity increases.

\section{Economic analysis}

Total feeding cost per calf was higher in male and female calves of IMS group as well as total feeding cost per calf per day. However, total cost per kg gain was quiet less in IMS group (Table III). Hence, intensive feeding could provide economical results.

Table III. Economic analysis of male and female camel calves in IMS and EMS.

\begin{tabular}{lllll}
\hline \multirow{2}{*}{ Costs } & \multicolumn{2}{c}{ IMS } & \multicolumn{2}{c}{ EMS } \\
\cline { 2 - 5 } & Male & Female & Male & Female \\
\hline Total feeding cost $/$ calf & $55 \$$ & $52 \$$ & $48 \$$ & $47 \$$ \\
Total feeding cost $/$ calf/d & $0.46 \$$ & $0.44 \$$ & $0.40 \$$ & $0.39 \$$ \\
Total cost $/ \mathrm{kg}$ gain & $0.68 \$$ & $0.67 \$$ & $0.94 \$$ & $1.03 \$$ \\
\hline
\end{tabular}

Grazing preference and behavioral feed intake

The forage species like kikar (Acacia nilotica), phulai (Acacia modesta), beri (Ziziphus mauritiana), siras (Albizia labbek), jand (Prosopis cineraria), khagal (Tamarix aphylla), dhaman (Cenchrus ciliaris), persain (Suaeda fruticosa), khawi (Cymbopogon schoenanthus), kali bui (Kochia indica), bhakra (Tribulus terrestris), kari (Capparis spinosa), laana (Haloxylon salincornicum), phog (Calligonam polygonoides), karir (Capparis decidua) and 
Table IV. Grazing preference of bushes, grasses and trees by camel calves under EMS.

\begin{tabular}{lllll}
\hline Score & Preference \%age & Bushes & Grasses & Trees \\
\hline 1 & $80-100 \%$ & Kari (Capparis spinosa) & Dhaman (Cenchrus ciliaris) & Kikar (Acacia nilotica) \\
2 & $60-79 \%$ & Laana (Haloxylon salincornicum) & Persain (Suaeda fruticosa) & Phulai (Acacia modesta) \\
3 & $40-59 \%$ & Phog (Calligonam polygonoides) & Khawi(Cymbopogon schoenanthus) & Beri leaves (Ziziphus mauritiana) \\
4 & $20-39 \%$ & Karir (Capparis decidua) & Kali Bui (Kochia indica) & Siras (Albizia labbek) \\
5 & $01-19 \%$ & KharLaana (Haloxylon recurvum) & Bhakra (Tribulus terrestris) & Jand (Prosopis cineraria) and \\
& & & & Khagal (Tamarix aphylla) \\
\hline
\end{tabular}

Table V. Feed intake of different grazing/browsing species by camel calves under EMS.

\begin{tabular}{llllll}
\hline Category & Species & No. of bites/h & Bite weight (g) & DMI (g/h) & DMI (\%) \\
\hline Bushes & Kari (Capparis spinosa) & 270 & 2.5 & 675 & 2.32 \\
& Laana (Haloxylon salincornicum) & 260 & 2.5 & 650 & 2.34 \\
& Phog (Calligonam polygonoides) & 210 & 3 & 630 & 2.42 \\
& Karir (Capparis decidua) & 200 & 3 & 600 & 2.24 \\
& KharLaana (Haloxylon recurvum) & 240 & 2.8 & 672 & 2.44 \\
Grasses & Dhaman (Cenchrus ciliaris) & 240 & 4.5 & 1080 & 3.11 \\
& Persain(Suaeda fruticosa) & 180 & 3 & 540 & 2.46 \\
& Khawi(Cymbopogon schoenanthus) & 90 & 3.5 & 315 & 1.93 \\
\multirow{5}{*}{ Trees } & Kali Bui (Kochia indica) & 204 & 3.5 & 714 & 2.05 \\
& Bhakra (Tribulus terrestris) & 160 & 2.5 & 400 & 2.57 \\
& Kikar (Acacia nilotica) & 220 & 2.8 & 616 & 2.16 \\
& Phulai (Acacia modesta) & 165 & 1.3 & 215 & 2.57 \\
& Beri leaves (Ziziphus mauritiana) & 264 & 1.7 & 449 & 2.48 \\
& Siras (Albizia labbek) & 210 & 2.5 & 525 & 2.79 \\
& Jand (Prosopis cineraria) & 228 & 3.5 & 798 & 2.53 \\
\end{tabular}

DMI, dry matter intake.

Table VI. Proximate analysis (\%) of crop residue and different grazing/browsing species.

\begin{tabular}{llllllll}
\hline Feed/ForageSpecies & DM & CP & EE & CF & NDF & ADF & Crude ash \\
\hline Gram straw (Cicer arientinum) & 93.53 & 9.72 & 2.60 & 44.4 & 68.7 & 47.6 & 7.83 \\
Kikar (Acacia nilotica) & 28.5 & 16.71 & 1.79 & 25.08 & 55.4 & 25.4 & 5.94 \\
Phulai (Acacia modesta) & 53.4 & 13.23 & 2.21 & 35.40 & 46.6 & 28.78 & 6.94 \\
Beri leaves (Ziziphus mauritiana) & 40.2 & 15.52 & 5.77 & 28.02 & 48.3 & 26.9 & 8.48 \\
Siras (Albizia labbek) & 37.3 & 16.17 & 6.58 & 27.25 & 43 & 29 & 16.33 \\
Jand (Prosopis cineraria) & 46.15 & 16.86 & 6.52 & 19.14 & 47.5 & 29 & 4.95 \\
Khagal (Tamarix aphylla) & 31.9 & 12.81 & 3.25 & 17.32 & 42.4 & 31.6 & 13.03 \\
Dhaman (Cenchrus ciliaris) & 31.9 & 14.69 & 3.94 & 26.51 & 38.53 & 18.15 & 15.71 \\
Persain (Suaeda fruticosa) & 30.3 & 10.57 & 5.52 & 33.14 & 48.7 & 27.6 & 7.54 \\
Khawi (Cymbopogon schoenanthus) & 34.6 & 9.53 & 2.01 & 35.67 & 62.1 & 43.5 & 7.14 \\
Kali Bui (Kochia indica) & 33.78 & 10.80 & 4.91 & 27.61 & 58.6 & 39.76 & 13.32 \\
Bhakra (Tribulus terrestris) & 32.1 & 8.76 & 4.58 & 32.63 & 46.7 & 35.4 & 9.64 \\
Kari (Capparis spinosa) & 36.7 & 17.84 & 1.18 & 30.75 & 51.8 & 33.5 & 6.97 \\
Laana (Haloxylon salincornicum) & 34.2 & 15.85 & 3.09 & 32.33 & 51.34 & 37.5 & 11.93 \\
Phog (Calligonam polygonoides) & 34.7 & 8.95 & 4.82 & 23.42 & 49.6 & 31.9 & 8.76 \\
Karir (Capparis decidua) & 49.4 & 16.75 & 1.52 & 24.64 & 53.6 & 37.8 & 14.76 \\
Khar laana (Haloxylon recurvum) & 47.9 & 12.36 & 3.32 & 24.95 & 49.2 & 31.3 & 12.15 \\
\hline
\end{tabular}

DM, dry matter; CP, crude protein; EE, ether extract; CF, crude fiber; NDF, neutral detergent fiber; ADF, acid detergent fiber 
khar laana (Haloxylon recurvum) were available species for browsing/grazing for calves. In the present study regarding grazing preference kari (Capparis spinosa), dhaman (Cenchrus ciliaris) and kikar (Acacia nilotica) got the first score (80-100\% preference) among bushes, grasses and trees, respectively (Table IV). Feed intake of different grazing/browsing species of camel calves depends upon the time spent over plant (number of bites during grazing/browsing) and bites weights. Regarding the feed intake, the top in order was kari (Capparis spinosa), dhaman (Cenchrus ciliaris) and jand (Prosopis cineraria) among bushes, grasses and trees respectively (Table V). This may be due to the higher protein contents of species (Table VI), specialty given by the nature to the animal to full fill its nutritional requirements efficiently in the desert grazing/browsing.

Bhakat et al. (2008) reported in India that phog (Calligonum polygonoides), ganthia (Dactyloctenium aegypticum) and khejri (Prosopis cineraria) were of first order in behavioral preference among bushes, grasses and trees, respectively. This may be due to the reason that these species have higher $\mathrm{CP}$ contents that could be the choice for browsing by camel calves as their natural dietary preference (Faye and Tisserand, 1989). Iqbal et al. (2001) reported that major plant species which forms the diet makeup of camel are Acacia modesta, Olea ferruginea and Alhaji camelorum while likeness of Acacia modesta in adults is due to its higher crude protein contents.

\section{CONCLUSIONS}

The findings of present study indicated that higher growth rate was achieved in IMS than EMS. Moreover, male calves were found to be heavier than female calves in both management systems. It is concluded that Pakistani camel calves have great production potential that could be exploited by modern husbandry practices according to scientific lines. So, it will be a useful addition to the food chain. Male calves should be utilized for meat production, while the higher growth rate of females should be utilized to achieve a more precocious reproduction age for heifers. It is further suggested that extension work is badly needed to convince the camel herders to adopt changing management and feeding practices in camel husbandry at their desert adobes.

\section{ACKNOWLEDGEMENTS}

The Author gratefully acknowledge the cooperation and kind support of the management of Camel Breeding and Research Station (CBRS) Rakh Mahni district Bhakkar, Punjab Pakistan and the camel herders from the vicinity to actively participate in the study. The financial support of Higher Education Commission (HEC) Islamabad, Pakistan, made this study possible.

\section{Statement of conflict of interset}

The author declare there is no conflict of interset.

\section{REFERENCES}

Ahmad, S., Yaqoob, M., Hashmi, N., Ahmad, S., Zaman, M.A. and Tariq, M., 2010. Economic importance of camel: A unique alternative under crises. Pak. Vet. J., 30: 191-197.

AOAC, 1997. Official methods of analysis of the association of official analytical chemists, Washington, D.C. U.S.A.

Bakheit, S.A., Idris, A., Faye, B. and Abdelhadi, O., 2012. The effect of management system on camel's milk yield and calve growth rate in North Kordofan, Sudan. Conf. Int. Res. on Food Security, Natural Resource Management and Rural Development, Sept, 19-21, Tropentag, Gottingen, Germany.

Bhakat, C., Saini, N. and Pathak, K.M.L., 2008. Effect of management systems on the performance of dromedary camel calves reared under organized farm condition. Indian J. Anim. Sci., 78: 1023-1027.

Bhakat, C., Saini, N. and Pathak, K.M.L., 2009. Growth characteristics, economics and hair mineral status of camel calves reared in different systems of management. Indian J. Anim. Sci., 79: 932-935.

Dabiri, N.G., Faiazi, J. and Shadmanesh, A., 2003. Effect of different levels of energy and protein on fattening performance of camels. Iranian J. agric. Sci., 34: 169-176.

El-Badawi, A.Y., 1996. The possibilities of using camels in new reclaimed lands. Proc. The first meeting of the National Committee for Camel Research in the Arab Republic of Egypt. 16 Nov. Cairo.

FAOSTAT, 2019. FAO Statistics Division. Rome, Italy.

Faraz, A., Mustafa, M.I., Lateef, M., Yaqoob, M. and Younas, M., 2013. Production potential of camel and its prospects in Pakistan. Punjab Univ. J. Zool., 28: 89-95.

Faraz, A., Younas, M., Lateef, M. and Muhammad, G., 2018. Effect of intensive and semi-intensive management systems on growth performance and economics of Marecha (Camelus dromedarius) calves reared under desert conditions. Pak. J. agric. Sci., 55: 625-632. https://doi.org/10.21162/ PAKJAS/18.4631 
Faraz, A., Younas, M., Lateef, M., Yaqoob, M. and Muhammad, G., 2017. Comparative growth performance of Marecha calves (Camelus dromedarius) reared under semi-intensive and extensive management systems. J. Anim. Pl. Sci., 27: 1067-1074.

Faraz, A., Waheed, A., Mirza, R.H. and Ishaq, H.M., 2019a. Role of camel in food security: a perspective aspect. J. Fish. Livest. Prod., 7: 290.

Faraz, A., Younas, M., Waheed, A., Yaqoob, M. and Ishaq, K., 2019b. Growth performance and hair mineral status of Marecha (Camelus dromedarius) calves reared under different management systems. Pakistan J. Zool., 51: 503-509. https://doi. org/10.17582/journal.pjz/2019.51.2.503.509

Faye, B., 2016. Food security and the role of local communities in the non-cow milk production. In: Non-bovine milk and milk products (eds. E. Tsakalidou and K. Papadimitriou), Elsevier and AP publ., London, UK, 1-13. https://doi.org/10.1016/ B978-0-12-803361-6.00001-6

Faye, B. and Tisserand, J.L., 1989. Problèmes de la détermination de la valeur alimentaire des fourrages prélevés par le dromadaire. Séminaire sur la nutrition et l'alimentation du dromadaire, Ouargla, Algérie. Options méditerr. Sér. sémin., 2: 61-65.

GOP, 2017-18. Economic Advisor's Wing. Ministry of Finance, Government of Pakistan Islamabad, Pakistan.

Hossner, K.L., 2005. Hormonal regulation offarmanimal growth. CABI Publishing, 875 Massachusetts Avenue, $7^{\text {th }}$ Floor, MA 02139, Cambridge, USA. https://doi.org/10.1079/9780851990804.0000

Iqbal, A., Khan, B.B., Younas, M., Gill, R.A. and Jasra, I.A.W., 2001. Comparative growth performance of camel calves kept under farm/farmer's conditions. Pak. J. agric. Sci., 38: 16-18.

Khanna, N.D., Rai, A.K. and Tandon, S.N., 2004. Camel breeds of India. The Camel Applied Research and Development Network (CARDN). J. Camel Sci., 1: 8-15.

Knoess, K.H., 1977. The camel as a meat and milk animal. World Anim. Rev., 22: 39-42.

Kurtu, M.Y., 2004. An assessment of the productivity for meat and carcass yield of camels (Camelus dromedarius) and of the consumption of camel meat in the eastern region of Ethiopia. Trop. Anim. Hlth. Prod., 36: 65-76. https://doi.org/10.1023/ B:TROP.0000009520.34657.35

Mohamedain, N.M., Fadlalla, I.M.T., Barri, M.E. and Abdel-Aziz, B.E., 2015. Growth performance in dromedary camels under two feeding regimen. The Regional Conference of Camel Management and Production under Open Range System (RCCMPR), Khartoum-Sudan, March, 2-4, 2015.

Musavaya, K., 2003. Weight development in camels of different age and sex classes under field conditions in a semi-arid area in northern Kenya. Master thesis, available at URL: http//www.troz.unihohenheim.de/research/Thesis/MScAP.

Ouda, J.O., Mbni, M.K. and Woie, B.M., 1992. Production performance of Somali and Rendille camels and their crossbreeds in northern Kenya. Paper presented at all African Conference on Animal Agriculture, Nairobi, Kenya.

Qureshi, M.H., 1986. The camel: A paper presented at a seminar on the camel, Kuwait. Oct. 20-23, FAO, Rome. pp: 1-35.

Rahim, S.M.A., Hasnain, S. and Farkhanda, J., 2011. Effect of calcium, magnesium, sodium and potassium on farm plantations of various agroecological zones of Punjab, Pakistan. Afr. J. Pl. Sci., 5: 450-459. https://doi.org/10.5897/ AJPS11.070

Raziq, A., Younas, M. and Kakar, M.A., 2008. Camel A potential dairy animal in difficult environments. Pak. J. agric. Sci., 45: 263-267.

Sahani, M.S., Bissa, U.K. and Khanna, N.D., 1998. Factors influencing pre and post weaning body weights and daily weight gain in indigenous breeds of camels under farm conditions. Proc. $3^{\text {rd }}$ Annual Meeting for Animal Production under Arid Conditions. UAE University, 1: 59-64.

Saini, N., Kiradoo, B.D. and Bohra, D.L., 2014. Impact of feeding on growth performance, blood biochemical and mineral profiles of pre-pubescent camels under pastoral management in arid western Rajasthan. Trop. Anim. Hlth. Prod., 46: 987-994. https://doi.org/10.1007/s11250-014-0589-2

Schroeder, J.W., 2013. Forage nutrition for ruminants. Quality Forage. NDSU Extension Service. AS1250 (Revised). pp. 1-16.

Singh, G.P., Nagpal, A.K., Saini, N. and Jayant, P., 2000. Studies on feed requirement and feed resources evaluation for optimum production. Annual Report, NRCC, Bikaner. pp. 26-34.

SPSS, Inc. Released 2008. SPSS Statistics for Windows, Version 17.0. Chicago: SPSS Inc. Chicago, IL. USA.

Steel, R.G.D., Torrie, J.H. and Dicky, D.A., 1997. Principles and procedures of statistics. A biometric approach. $3^{\text {rd }}$ Ed. McGraw Hill Book Co., New York, USA. 
Tandon, S.N., Khanna, N.D. and Sharma, N., 1993. To develop suitable management practices for rearing camels. Annual Report, NRCC, Bikaner, pp. 45-49.

Van Soest, P.J., Robertson, J.B. and Lewis, B.A., 1991. Method for dietary fiber, neutral detergent fiber, and nonstarch polysaccharides in relation to animal nutrition. J. Dairy Sci., 74: 3583-3597. https://doi. org/10.3168/jds.S0022-0302(91)78551-2

Von Engelhardt, W., Haarmeyer, P., Lechner-Doll, M., 2006. Feed intake, fore stomach fluid volume, dilution rate and mean retention of fluid in the forestomach during water deprivation and rehydration in camels (Camelus sp.). Comp. Biochem. Physiol. Part A: Mol. Integr. Physiol., 143: 504-507. https://doi. org/10.1016/j.cbpa.2006.01.021

Wilson, R.T., 1998. Camels. In: The tropical agriculturalist. A book by McMillan Education Ltd. London, UK.

Wilson, R.T., 1992. Factors affecting weight and growth in one humped camels. Proceeding of First International Camel Conference, February 2-6, Dubai. pp. 309-312. 